\title{
INVENTARISASI SPERMATOPHYTA DI PONPES NURIS JEMBER TAHUN AJARAN 2021
}

\author{
Ade Yusfin Damayanti ${ }^{1}$, Mohammad Wildan Habibi ${ }^{2}$ \\ 1. Progam Studi Tadris Biologi, Fakultas Tarbiyah dan Ilmu Keguruan, IAIN Jember \\ 2. Progam Studi Tadris IPA, Fakultas Tarbiyah dan Ilmu Keguruan, IAIN Jember \\ Email: yusfindamara@yahoo.com
}

\begin{abstract}
ABSTRAK
Pondok Pesantren Nuris Jember memiliki julukan sebagai Green Campus karena keanekaragaman tumbuhan hijaunya yang terdapat di kawasan pondok pesantren ini. Mayoritas tumbuhannya adalah jenis tumbuhan berbiji (spermatophyta). Tujuan penelitian ini adalah untuk mengetahui jenis-jenis tumbuhan yang ada di Pondok Pesantren Nuris Jember. Penelitian ini menggunakan pendekatan kualitatif dengan jenis penelitian deskriptif. Sumber data penelitian ini adalah tumbuhan spermatophyta di Yayasan Pondok Pesantren Nuris Jember. Hasil penelitian menunjukkan bahwa terdapat 43 jenis tumbuhan dengan rincian satu spesies Gymnospermae dan 42 spesies dari Angiospermae yang terdiri dari 13 spesies tumbuhan biji keping satu (monocotyledoneae) dan 29 spesies tumbuhan biji keping dua (dicotyledoneae). Sehingga keanekaragaman tumbuhan di kawasan Pondok Pesantren Nuris didominasi dengan tumbuhan Angiospermae kelas dicotyledoneae.
\end{abstract}

Kata Kunci: Nuris,Tumbuhan, Spermatophyta, Spesies

\begin{abstract}
Nuris Islamic Boarding School Jember bears the nickname Green Campus because of the diversity of green plants found within their area. Most of the are seed plant (spermatophyte). The purpose of this study was to identify different types of plants that grow in Nuris Islamic Boarding School Jember. This study used qualitative approarch employing descriptive research. The source of the data for this research are the spermatophyte plants within Nuris Islamic Boarding School Jember. The result showed that there were 43 plants species with one of the species is Gymnospermae and 42 species are Angiospermae which consisted of 13 species of monocotyledoneae and 29 species of dicotyledoneae. Therefore, the diversity of plants in the Nuris Islamic Boarding School is dominated by Angiospermae class dicotyledoneae.
\end{abstract}

Keyword: Nuris,Plants, Spermatophyta, Spesies

\section{PENDAhUluan}

Pondok pesantren adalah tempat berkumpulnya santri atau orang-orang yang menuntut ilmu agama kepada seorang guru yang biasa disebut dengan kyai dan syaikh (Syafe'I, 2017). Pondok pesantren harus memperhatikan aspek daya tampung, kenyamanan, kebersihan, kesehatan dan keamanan (RUU Pesantren No 18 Tahun 2019). Sehingga pondok pesantren menjadi tempat tinggal atau rumah bagi seseorang 
yang belajar. Bangunan dan tata ruang pondok pesantren tidak terdiri dari petak-petak kamar, masjid, dan sekolah saja namun terdapat lahan kosong yang difungsikan sebagai taman mini pondok pesantren, lahan bercocok tanam sayur dan buah-buahan juga tanaman hias guna memberikan nuansa nyaman yang bernilai estetika.

Pondok Pesantren Nuris terletak di Jalan Pangandaran no.46 Antirogo Sumbersari Jember dijuluki sebagai Green Campus (kampus hijau) karena sesuai dengan kondisi lingkungan pondok pesantren ini yang memiliki bermacam-macam tumbuhan hijau, terutama tumbuhan tingkat tinggi (spermatophyta) baik di kawasan pondok pesantren maupun di lembaga sekolah. Hal ini menjadi salah satu cara dalam menjaga kelestarian dan menambah keberagaman tumbuhan di pekarangan. Keanekaragaman tumbuhan di pekarangan merupakan salah satu potensi lokal yang perlu dilestarikan, salah satunya dengan membelajarkan kepada masyarakat di lingkungan tersebut (Febriarta, 2011).

Hal ini selaras dengan penelitian yang dilakukan oleh Sumiati (2018) mahasiswa Fakultas Tarbiyah dan Ilmu Keguruan Universitas Islam Negeri Ar-Raniry Darussalam Banda Aceh dengan judul "Inventarisasi Jenis Tumbuhan Pekarangan di Penampaan Uken Kecamatan Blankejeren Gayo Lues Sebagai Media Pembelajaran Biologi”. Hasil penelitian ini menunjukkan ada 86 jenis tumbuhan spermatophyta di Penampaan Uken yang dapat dijadikan media pembelajaran biologi.

Berdasarkan pemaparan tersebut maka peneliti bermaksud melakukan penelitian dengan judul "Inventarisasi Spermatophyta Sebagai Media Pembelajaran Materi Plantae Kelas X MIPA SMA Nuris Jember Tahun Ajaran 2020/2021”.

\section{METODE PENELITIAN}

\subsection{Rancangan Penelitian}

Penelitian ini menggunakan metode eksploratif untuk memperoleh data. Penelitian eksploratif adalah suatu metode observasi langsung ke tempat penelitian dilakukan. Penelitian ini dilakukan dengan melakukan jelajah dan pengamatan secara 
langsung terhadap jenis tanaman yang terdapat di kawasan Pondok Pesantren Nuris Jember.

\subsection{Lokasi dan Waktu Penelitian}

Penelitian ini dilaksanakan di kawasan Pondok Pesantren Nuris Jember pada bulan Juli 2020.

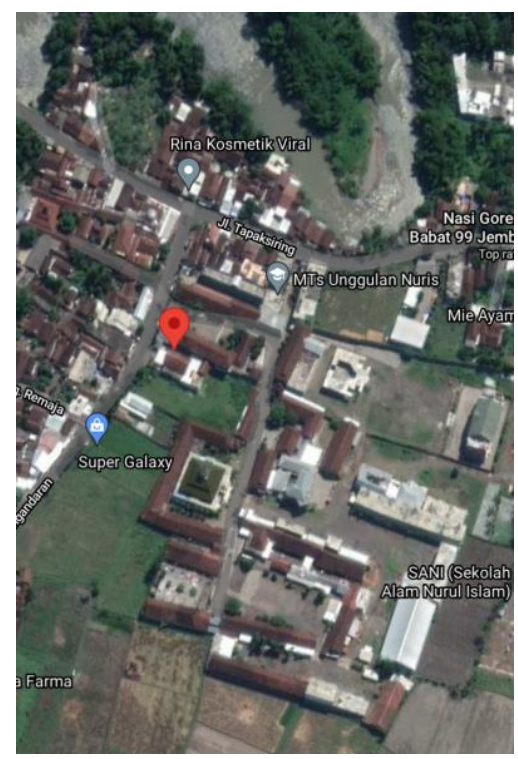

Gambar 3.1 Lokasi Penelitian

\subsection{Populasi dan Sampel}

Populasi dalam penelitian ini adalah semua jenis tumbuhan pekarangan yang terdapat di kawasan Pondok Pesantren Nuris Jember. Sedangkan yang menjadi sampel adalah tumbuhan spermatophyta yang terdapat di kawasan Pondok Pesantren Nuris Jember yang telah diketahui spesiesnya berdasarkan ciri-ciri yang dimiliki tumbuhan spermatophyta. Sedangkan tumbuhan yang belum diketahui spesiesnya akan diidentifikasi lebih lanjut.

\subsection{Alat dan Bahan}

Alat dan bahan yang diguanakan dalam penelitian ini meliputi: kamera (untuk memotret sampel sebagai dokumentasi), pisau (untuk memoton bagian tumbuhan yang belum diketahui klasifikasinya), plastik sampel (untuk menyimpan potongan sampel), 
serta buku panduan flora, aplikasi PlanNet Identification versi 3.2.6 2020 dan website Plantamor 2020 (sebagai panduan dalam mengidentifikasi tumbuhan spermatophyta).

\subsection{Teknik Pengumpulan Data}

Teknik pengumpulan data yang digunakan dalam penelitian ini adalah observasi atau pengamatan langsung terhadap tumbuhan spermatophyta yang ada di lokasi penelitian. Selanjutnya menggunakan metode ekploratif atau jelajah dengan cara menyisir semua lokasi yang telah ditentukan. Tumbuhan spermatophyta dipotret untuk dokumentasi dan dicatat pada tabel lembar kerja yang telah disediakan. Untuk tumbuhan yang belum diketahui klasifikasinya, bagian tubuh tumbuhan tersebut dipotong untuk dijadikan sampel identifikasi lanjutan. Seluruh tumbuhan diidentifikasi menggunakan buku Taksonomi Tumbuhan Spermatophyta karya Gembong Tjitrooepomo, aplikasi PlanNet Identification versi 3.2.6 2020 dan website Plantamor 2020.

\subsection{Teknik Analisis}

Data dianalisis dengan cara deskriptif dalam bentuk tabel yang berisi foto tumbuhan asli, foto pembanding, dan klasifikasi tiap spesies juga disajikan dalam analisis deskriptif.

\section{HASIL DAN PEMBAHASAN}

Tumbuhan berbiji (spermatophyta) di yayasan Pondok Pesantren Nuris Jember berjumlah 43 spesies, berikut data hasil identifikasinya:

\begin{tabular}{|c|l|ll|}
\hline No & Foto Tanaman & \multicolumn{1}{c|}{ Klasifikasi } \\
\hline 1 & & Kingdom & $:$ Plantae \\
& & Subkingdom & $:$ Tracheobionta \\
& & Superdivisi & $:$ Spermatophyta \\
& & Divisi & $:$ Coniferophyta \\
& & Kelas & $:$ Pinopsida \\
& & Ordo & $:$ Pinales \\
& & Famili & $:$ Araucariaceae \\
& & Genus & $:$ Araucaria \\
\hline 2 & & Spesies & $:$ Araucaria heterophylla (Salisb.) Fran \\
& & Kingdom & $:$ Plantae \\
& & Subking & $:$ Tracheobionta \\
& & Supdivisi & $:$ Spermatophyta \\
& & Divisi & $:$ Magnoliophyta \\
\hline
\end{tabular}




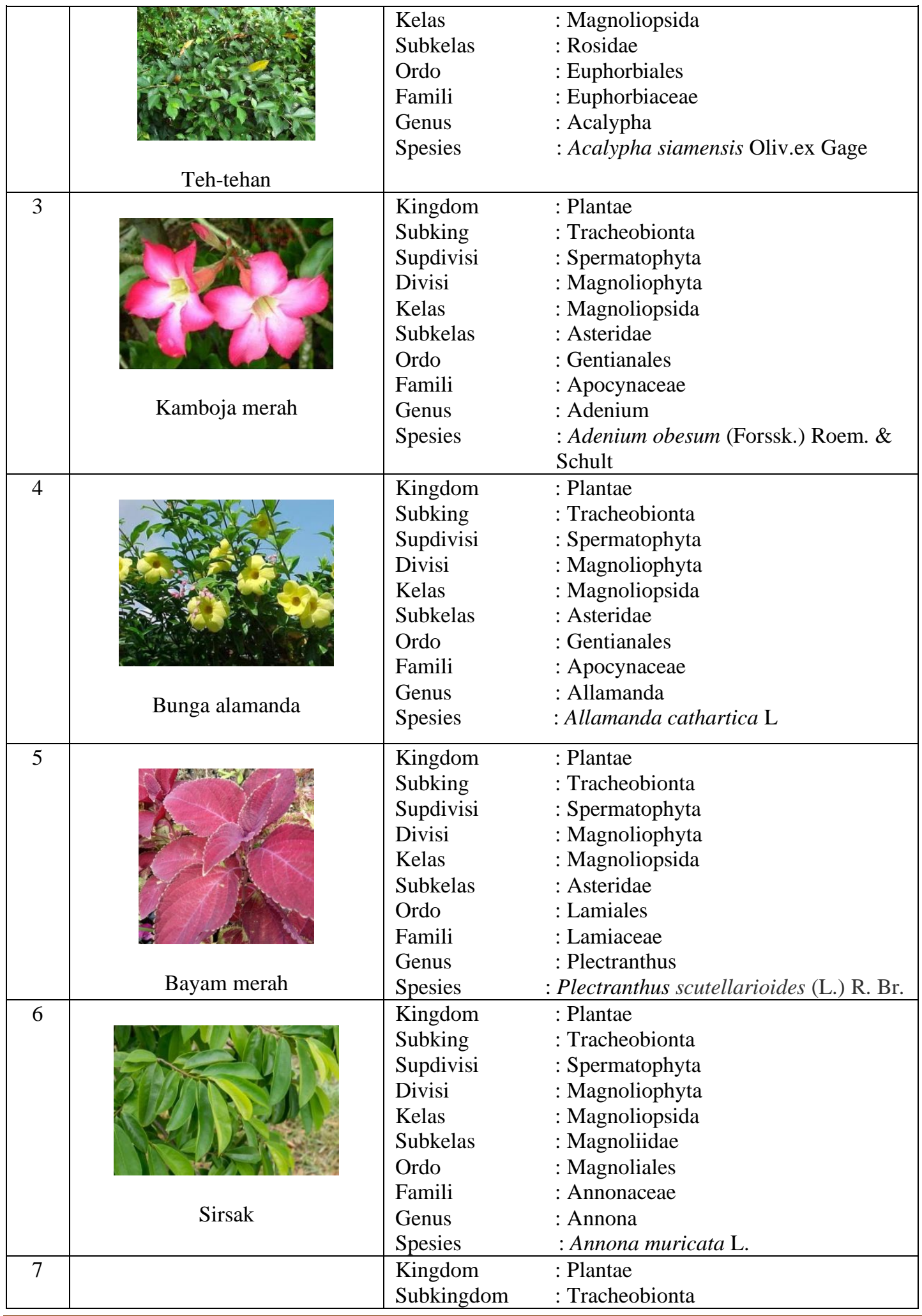




\begin{tabular}{|c|c|c|c|}
\hline & Nangka & $\begin{array}{l}\text { Superdivisi } \\
\text { Divisi } \\
\text { Kelas } \\
\text { Subkelas } \\
\text { Ordo } \\
\text { Famili } \\
\text { Genus } \\
\text { Spesies }\end{array}$ & $\begin{array}{l}\text { : Spermatophyta } \\
\text { : Magnoliophyta } \\
\text { : Magnoliopsida } \\
\text { : Hamamelididae } \\
\text { : Urticales } \\
\text { : Moraceae } \\
\text { : Artocarpus } \\
\text { : Artocarpus heterophyllus Lam }\end{array}$ \\
\hline 8 & Bunga bugenvil & $\begin{array}{l}\text { Kingdom } \\
\text { Subkingdom } \\
\text { Superdivisi } \\
\text { Divisi } \\
\text { Kelas } \\
\text { Subkelas } \\
\text { Ordo } \\
\text { Famili } \\
\text { Genus } \\
\text { Spesies }\end{array}$ & $\begin{array}{l}\text { : Plantae } \\
\text { : Tracheobionta } \\
\text { : Spermatophyta } \\
\text { : Magnoliophyta } \\
\text { : Magnoliopsida } \\
\text { : Caryophyllidae } \\
\text { : Caryophyllales } \\
\text { : Nyctaginaceae } \\
\text { : Bougainvillea } \\
\text { : Bougainvillea glabra } \text { Choisy }\end{array}$ \\
\hline 9 & Papaya & $\begin{array}{l}\text { Kingdom } \\
\text { Subkingdom } \\
\text { Superdivisi } \\
\text { Divisi } \\
\text { Kelas } \\
\text { Subkelas } \\
\text { Ordo } \\
\text { Famili } \\
\text { Genus } \\
\text { Spesies }\end{array}$ & $\begin{array}{l}\text { : Plantae } \\
\text { : Tracheobionta } \\
\text { : Spermatophyta } \\
\text { : Magnoliophyta } \\
\text { : Magnoliopsida } \\
\text { : Dilleniidae } \\
\text { : Violales } \\
\text { : Caricaceae } \\
\text { : Carica } \\
\text { : Carica papaya } \mathrm{L} .\end{array}$ \\
\hline 10 & Kaktus koboi & $\begin{array}{l}\text { Kingdom } \\
\text { Subkingdom } \\
\text { Superdivisi } \\
\text { Divisi } \\
\text { Kelas } \\
\text { Subkelas } \\
\text { Ordo } \\
\text { Famili } \\
\text { Genus } \\
\text { Spesies }\end{array}$ & $\begin{array}{l}\text { : Plantae } \\
\text { : Tracheobionta } \\
\text { : Spermatophyta } \\
\text { : Magnoliophyta } \\
\text { : Magnoliopsida } \\
\text { : Caryophyllidae } \\
\text { : Caryophyllales } \\
\text { : Cactaceae } \\
\text { : Cereus } \\
\text { : Cereus hexagonus }(\text { L.) Mill. }\end{array}$ \\
\hline 11 & $\begin{array}{l}\text { ato } \\
\text { Puring }\end{array}$ & $\begin{array}{l}\text { Kingdom } \\
\text { Subkingdom } \\
\text { Superdivisi } \\
\text { Divisi } \\
\text { Kelas } \\
\text { Subkelas } \\
\text { Ordo } \\
\text { Famili } \\
\text { Genus } \\
\text { Spesies }\end{array}$ & $\begin{array}{l}\text { : Plantae } \\
\text { : Tracheobionta } \\
\text { : Spermatophyta } \\
\text { : Magnoliophyta } \\
\text { : Magnoliopsida } \\
\text { : Rosidae } \\
\text { : Euphorbiales } \\
\text { : Euphorbiaceae } \\
\text { : Codiaeum } \\
\text { : Codiaeum variegatum (L.) A. Juss. }\end{array}$ \\
\hline 12 & & $\begin{array}{l}\text { Kingdom } \\
\text { Subkingdom }\end{array}$ & $\begin{array}{l}\text { : Plantae } \\
\text { : Tracheobionta }\end{array}$ \\
\hline
\end{tabular}




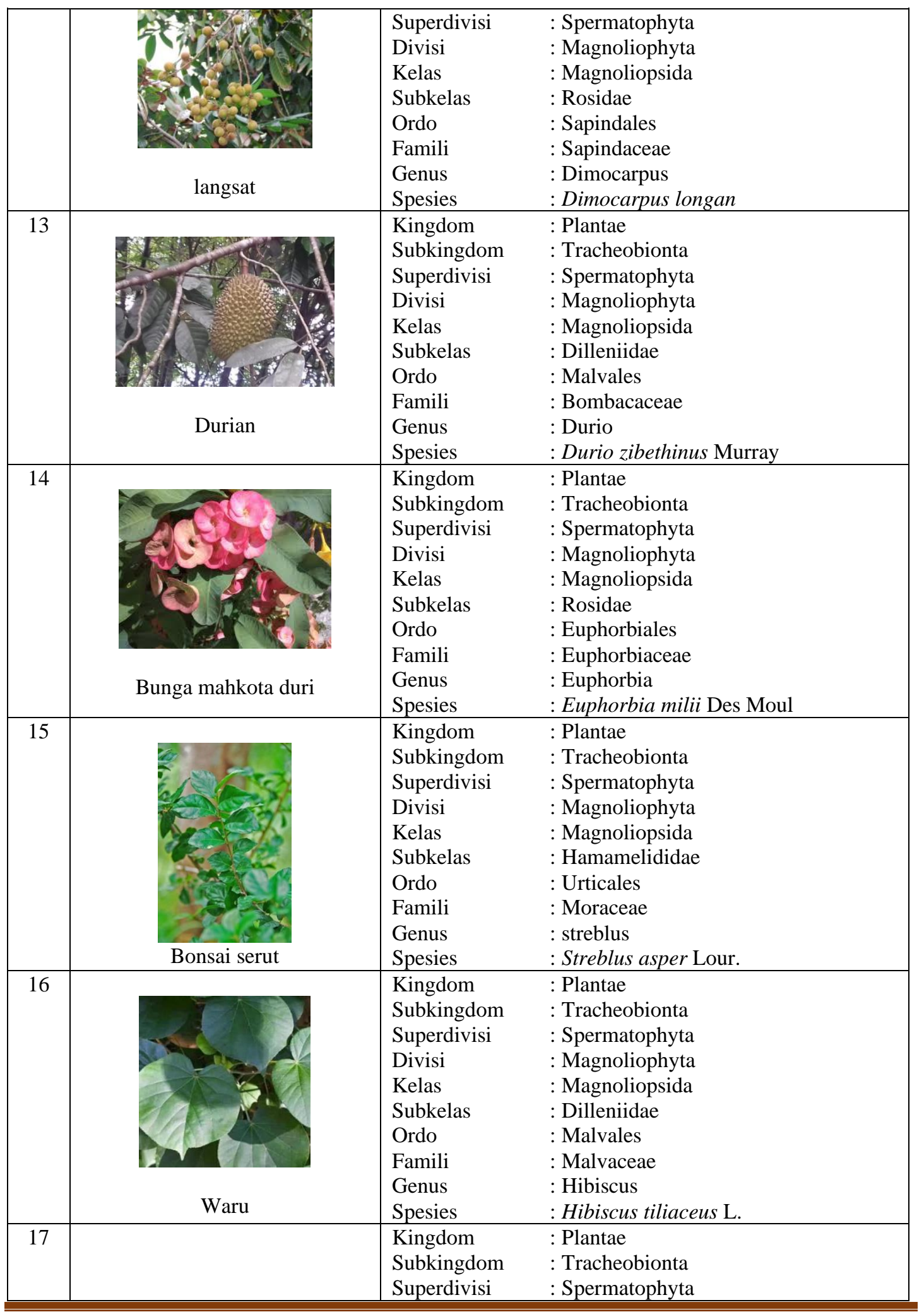




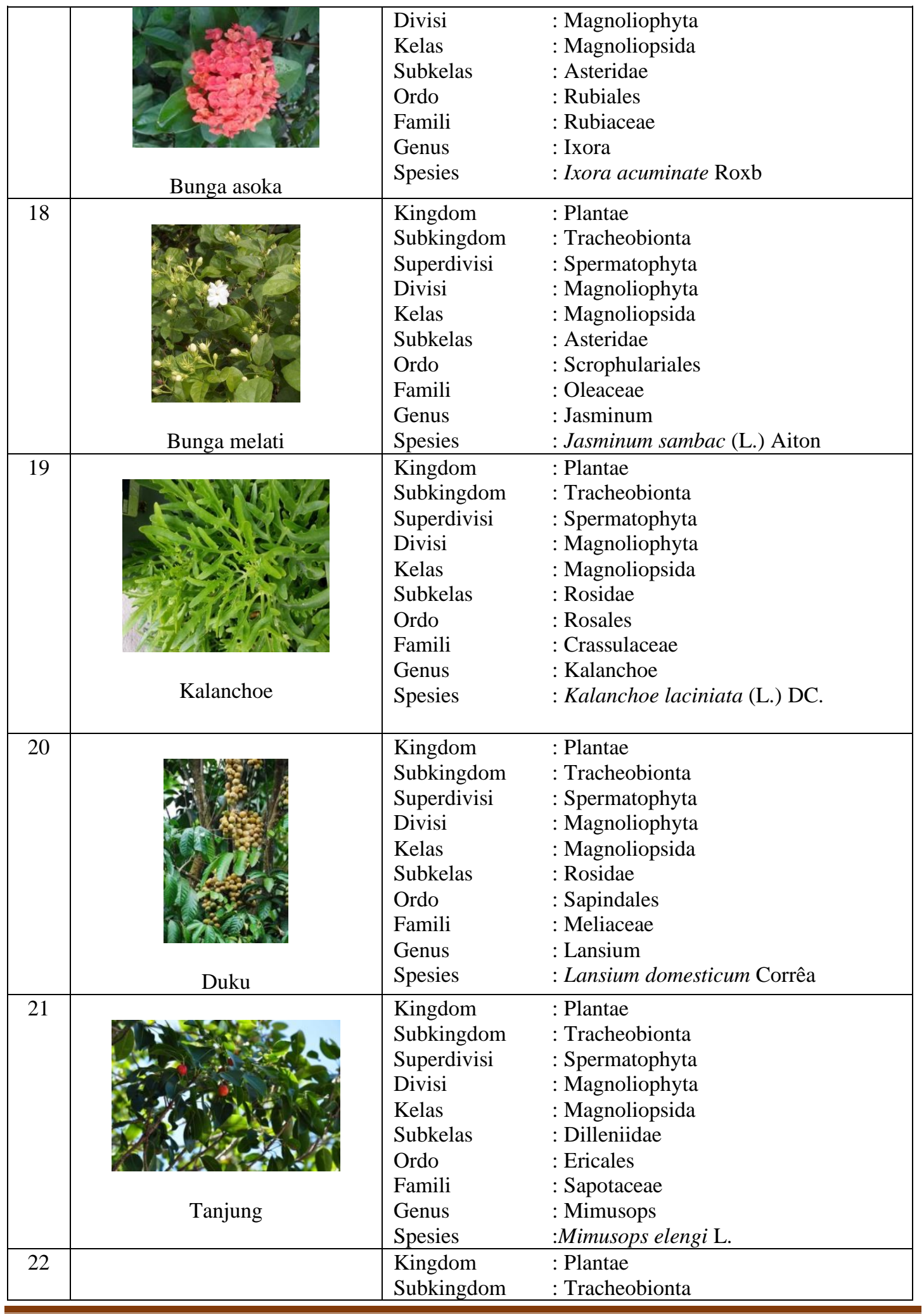




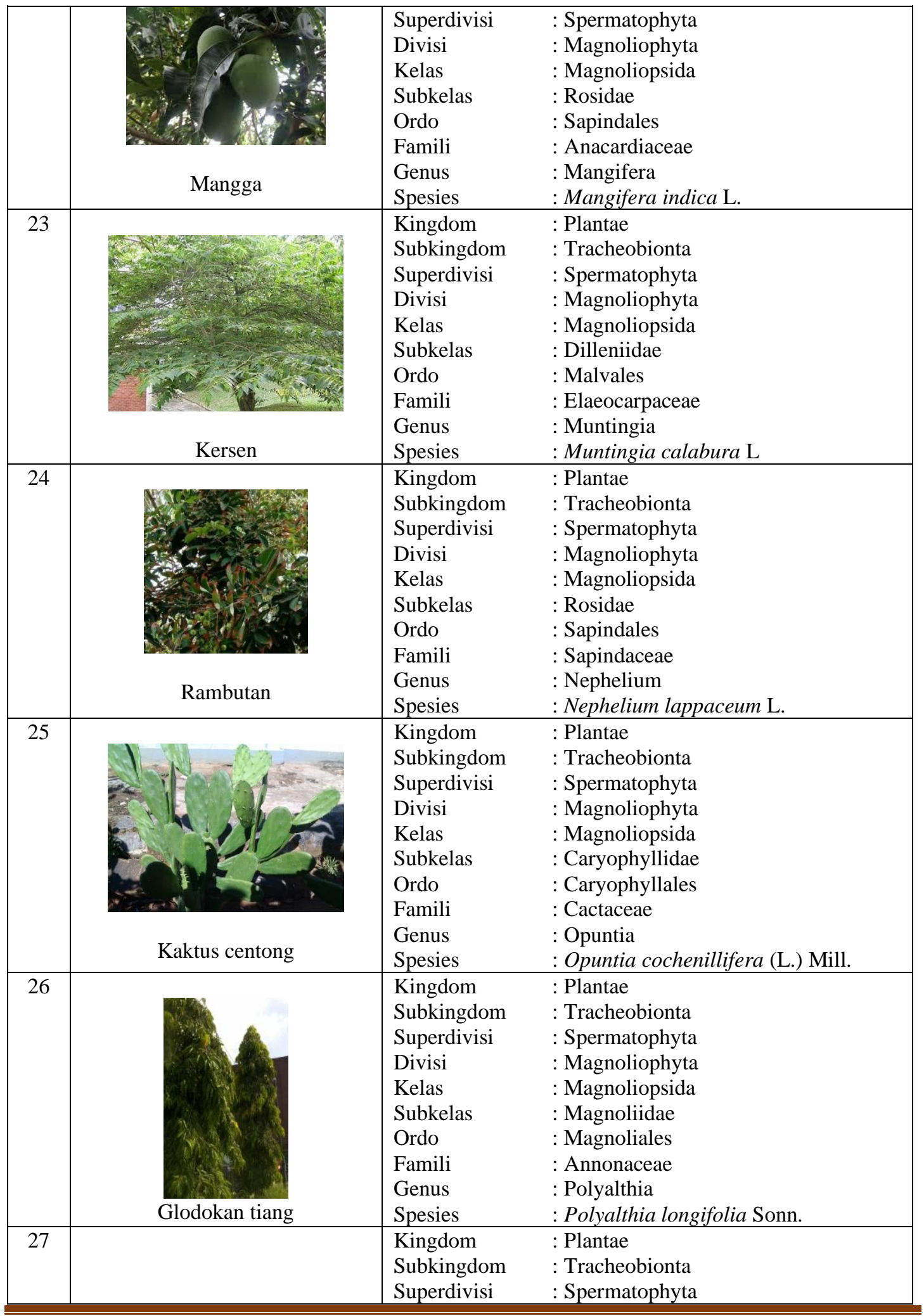




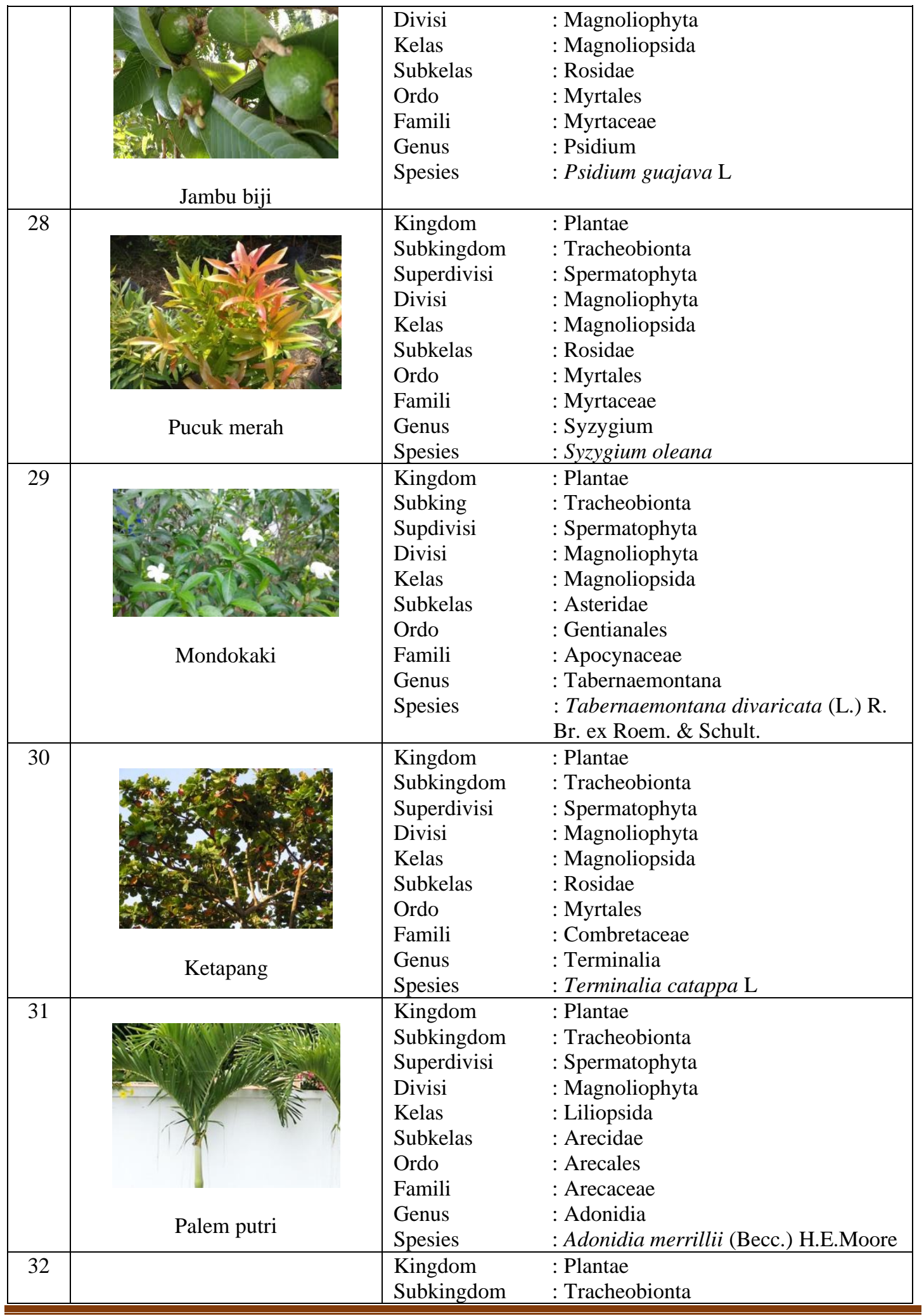




\begin{tabular}{|c|c|c|c|}
\hline & Agave kuning & $\begin{array}{l}\text { Superdivisi } \\
\text { Divisi } \\
\text { Kelas } \\
\text { Subkelas } \\
\text { Ordo } \\
\text { Famili } \\
\text { Genus } \\
\text { Spesies } \\
\end{array}$ & $\begin{array}{l}\text { : Spermatophyta } \\
\text { : Magnoliophyta } \\
\text { : Liliopsida } \\
\text { : Lilidae } \\
\text { : Asparagales } \\
\text { : Asparagaceae } \\
\text { : Furcraea } \\
\text { : Furcraea gigantea }\end{array}$ \\
\hline 33 & Hanjuang & $\begin{array}{l}\text { Kingdom } \\
\text { Subkingdom } \\
\text { Superdivisi } \\
\text { Divisi } \\
\text { Kelas } \\
\text { Subkelas } \\
\text { Ordo } \\
\text { Famili } \\
\text { Genus } \\
\text { Spesies }\end{array}$ & $\begin{array}{l}\text { : Plantae } \\
\text { : Tracheobionta } \\
\text { : Spermatophyta } \\
\text { : Magnoliophyta } \\
\text { : Liliopsida } \\
\text { : Liliidae } \\
\text { : Asparagales } \\
\text { : Asparagaceae } \\
\text { : Cordyline } \\
\text { : Cordyline fruticosa }(\text { L.) Ker Gawl. }\end{array}$ \\
\hline 34 & Drakaena merah & $\begin{array}{l}\text { Kingdom } \\
\text { Subkingdom } \\
\text { Superdivisi } \\
\text { Divisi } \\
\text { Kelas } \\
\text { Subkelas } \\
\text { Ordo } \\
\text { Famili } \\
\text { Genus } \\
\text { Spesies }\end{array}$ & $\begin{array}{l}\text { : Plantae } \\
\text { : Tracheobionta } \\
\text { : Spermatophyta } \\
\text { : Magnoliophyta } \\
\text { : Liliopsida } \\
\text { : Liliidae } \\
\text { : Liliales } \\
\text { : Liliaceae } \\
\text { : Cordyline } \\
\text { : Cordyline australis (G.Forst.) Endl. }\end{array}$ \\
\hline 35 & Drakaena hijau & $\begin{array}{l}\text { Kingdom } \\
\text { Subkingdom } \\
\text { Superdivisi } \\
\text { Divisi } \\
\text { Kelas } \\
\text { Subkelas } \\
\text { Ordo } \\
\text { Famili } \\
\text { Genus } \\
\text { Spesies }\end{array}$ & $\begin{array}{l}\text { : Plantae } \\
\text { : Tracheobionta } \\
\text { : Spermatophyta } \\
\text { : Magnoliophyta } \\
\text { : Liliopsida } \\
\text { : Liliidae } \\
\text { : Asparagales } \\
\text { : Asparagaceae } \\
\text { : Dracaena } \\
\text { : Dracaena reflexa }\end{array}$ \\
\hline 36 & Sri rejeki & $\begin{array}{l}\text { Kingdom } \\
\text { Subkingdom } \\
\text { Superdivisi } \\
\text { Divisi } \\
\text { Kelas } \\
\text { Subkelas } \\
\text { Ordo } \\
\text { Famili } \\
\text { Genus } \\
\text { Spesies }\end{array}$ & $\begin{array}{l}\text { : Plantae } \\
\text { : Tracheobionta } \\
\text { : Spermatophyta } \\
\text { : Magnoliophyta } \\
\text { : Liliopsida } \\
\text { : Arecidae } \\
\text { : Arales } \\
\text { : Araceae } \\
\text { : Dieffenbachia } \\
\text { : Dieffenbachia seguine (Jacq.) Schott }\end{array}$ \\
\hline
\end{tabular}


BIOSENSE Vol. 04 No. 1, Juni 2021

ISSN : $2622-6286$

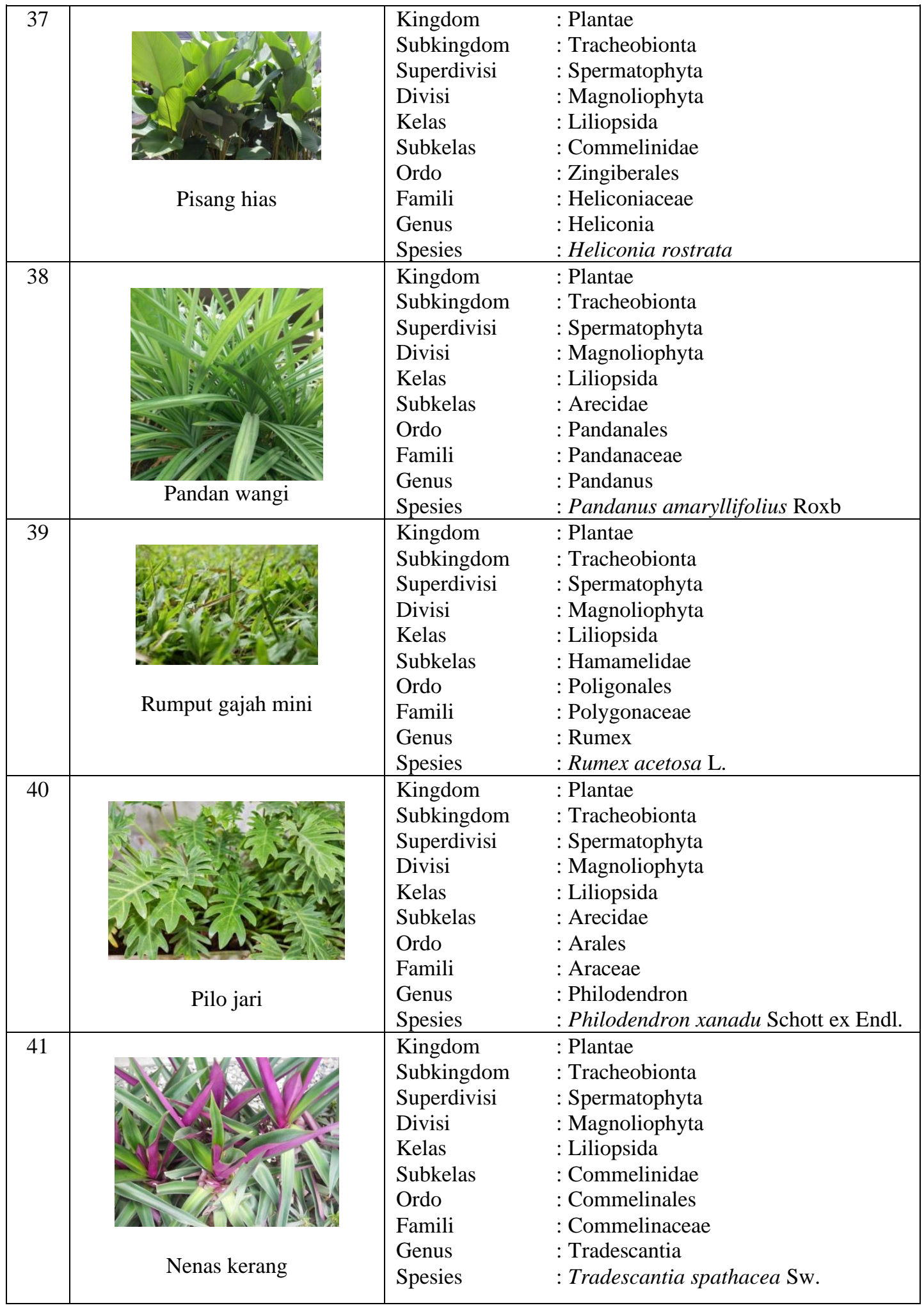




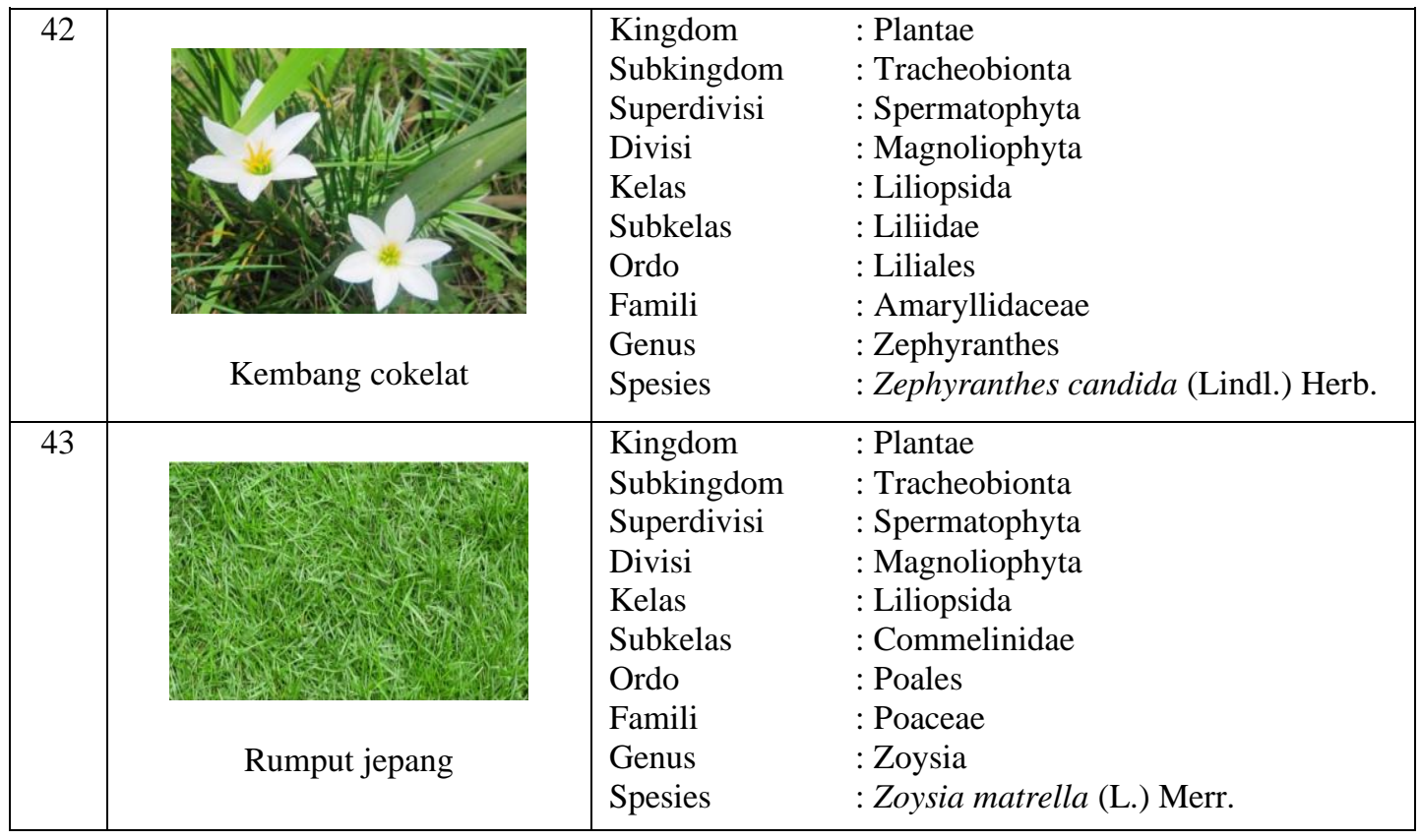

Keberagaman tumbuhan berbiji (spermatophyta) di yayasan Pondok Pesantren Nuris Jember berjumlah 43 jenis. Satu spesies Gymnospermae. 42 spesies dari Angiospermae yang terdiri dari 13 spesies tumbuhan biji keping satu (monocotyledoneae) atau Liliopsida dan 29 spesies tumbuhan biji keping dua (dicotyledoneae) atau Magnoliopsida.

Satu spesies Gymnospermae yakni family Araucariaceae dengan spesies Araucaria heterophylla (Salisb.) Franco atau cemara natal. 13 spesies tumbuhan biji keping satu (monocotyledoneae) atau Liliopsida terdiri dari famili Arecaceae,Asparagaceae, Liliaceae, Araceae,Heliconiaceae, pananaceae, Polygonaceae, Commelinaceae, Amaryllidaceae, Poaceae.

Sedangkan 29 spesies tumbuhan biji keping dua (dicotyledoneae) atau Magnoliopsida terdiri dari famili Apocynaceae, Euporbiaceae, Lamiaceae, Annonaceae, Moraceae, Nyctaginaceae, Caricaeae, Cactacea, Sapindaceae, Bombacaceae, Malvaceae, Rubiaceae, Oleaceae, Crassulaceae, Meliaceae, Sapotaceae, Anacariaceae, Elacocarpaceae, Combretaceae. 


\section{KESIMPULAN DAN SARAN}

Berdasarkan penelitian yang telah dilakukan dapat disimpulkan sebagai berikut:

Terdapat 43 jenis tumbuhan dengan rincian satu spesies Gymnospermae dan 42 spesies dari Angiospermae yang terdiri dari 13 spesies tumbuhan biji keping satu (monocotyledoneae) dan 29 spesies tumbuhan biji keping dua (dicotyledoneae). Keanekaragaman tumbuhan berbiji (spermatophyta) di kawasan Pondok Pesantren Nuris didominasi dengan tumbuhan Angiospermae kelas dicotyledoneae.

\section{REFERENSI}

Febriarta, Her Anggara. "Identifikasi Karakteristik dan Fungsi Tanaman Hias untuk Taman Rumah di Dataran Medium dan Dataran Rendah”. Skripsi Universitas Gadjah Mada: Yogyakarta. 2011.

PlanNet Identification versi 3.2.6 2020

Plantamor 2020

RUU Pesantren No.18 Tahun 2019.

Sumiati. 2018. "Inventarisasi Jenis Tumbuhan Pekarangan di Kampung Panampaan Uken Kecamatan Blangkejeren Gayo Lues sebagai Media Pembelajaran Biologi”. Skripsi FKIP. Pendidikan Biologi. Universitas Islam Negeri ArRaniry: Darussalam-Banda Aceh.

Syafe'i, Imam. "Pondok Pesantren: Lembaga Pendidikan Pembentukan Karakter". Jurnal Pendidikan Agama Islam. Vol 8 (1). 2017.

Tjitrosoepomo, Gembong. Taksonomi Tumbuhan. Yogyakarta: UGM Press. 2009

Tjitrosoepomo, Gembong. Taksonomi Tumbuhan Spermatophyta. Yogyakarta: UGM Press. 2010. 